\title{
The Effects of Multimedia-Supported Problem-based Inquiry on Student Engagement, Empathy, and Assumptions About History
}

Thomas Brush

John Saye

IJPBL is Published in Open Access Format through the Generous Support of the Teaching Academy at Purdue University, the School of Education at Indiana University, and the Jeannine Rainbolt College of Education at the University of Oklahoma.

\section{Recommended Citation}

Brush, T. , \& Saye, J. (2008). The Effects of Multimedia-Supported Problem-based Inquiry on Student Engagement, Empathy, and Assumptions About History. Interdisciplinary Journal of Problem-Based Learning, 2(1).

Available at: https://doi.org/10.7771/1541-5015.1052

This document has been made available through Purdue e-Pubs, a service of the Purdue University Libraries. Please contact epubs@purdue.edu for additional information.

This is an Open Access journal. This means that it uses a funding model that does not charge readers or their institutions for access. Readers may freely read, download, copy, distribute, print, search, or link to the full texts of articles. This journal is covered under the CC BY-NC-ND license. 


\title{
The Effects of Multimedia-Supported Problem-based Inquiry on Student Engagement, Empathy, and Assumptions About History
}

\author{
Thomas Brush
}

John Saye

\begin{abstract}
This research extends a continuing line of inquiry investigating how multimedia resources might be joined with other support structures to effectively implement problem-based inquiry (PBI) activities in secondary history classrooms. Two history teachers with experience in PBI implemented a technology-supported problem-based civil rights unit in their classrooms. Analysis of data obtained from classroom observations, observations of student presentations, and student and teacher interviews suggests that the multimedia problem-based unit provided an authentic context for encountering historical content, provoked empathetic views of historical dilemmas, and encouraged meaningful encounters with historical issues that promoted engagement and more advanced epistemological beliefs about history. Suggestions for improving scaffolds to support problem-based history activities are also presented based on the findings from this study.

Keywords: multimedia, history, engagement, civil rights
\end{abstract}

\section{Background}

Over the past several years, researchers have posited that the investigation of authentic, complex problems is an effective method to engage learners deeply with a variety of content and to develop better decision makers and problem solvers (Hmelo-Silver, 2004; Jonassen, 1997, 1999; Kolodner et al., 2003). This approach, defined as problembased inquiry $(\mathrm{PBI})$, presents learners with an authentic, ill-structured problem and 
resources to assist with solving the problem. Problem-based inquiry is similar to problem-based learning in that learners interact with resources, develop strategies for utilizing the resources to address the problem, and present and negotiate solutions to the problem in a collaborative manner (Hannafin, Hill, \& Land, 1997; Hmelo-Silver, 2004; Hmelo-Silver, Duncan, \& Chinn, 2007). In problem-based inquiry, however, the teacher serves a much more direct role in both facilitating the inquiry process and serving as a knowledge resource to learners (Savery, 2006). It is believed that problem-based inquiry assists learners with constructing a more extensive and flexible knowledge base, developing more effective problem-solving skills, and improving collaborative abilities (Barrows \& Kelson, 1995; Hmelo-Silver, 2004).

Numerous examples of successful implementations of problem-based inquiry have been shown in a variety of content areas, including mathematics (CTGV, 1992, 1993; Hickey, Moore, \& Pellegrino, 2001), science (Geier et al., in press; Kolodner et al., 2003; Linn, Shear, Bell, \& Slotta, 1999; Loh et al., 2001; Pedersen \& Liu, 2003; Simons \& Klein, 2007), economics (Mergendoller, Maxwell, \& Bellisimo, 2006; Ravitz \& Mergendoller, 2005), and literature (Jacobsen \& Spiro, 1994). In most high school history classrooms, however, problem-based curriculum reform has not been widely accepted and adopted by teachers (Onosko, 1991; Saye \& Brush, 2004; Shaver, 1996; Shaver, Davis, \& Helburn, 1979; Zukas, 2000), despite the fact that social educators have advocated that history instruction move away from the goal of mere retention of historical information and toward "... understand[ing] history as a problem-solving activity ..." (Dundis \& Fehn, 1999, p. 273).

\section{Effective Problem-based Inquiry in the History Classroom}

The ability to reason critically about complex problems is important in virtually any content domain. However, the multilogical and controversial nature of historical problems necessitates the kinds of reasoning that are different from well-structured problems of logic (Perkins, Allen, \& Hafner, 1983). Researchers have found that novice problem solvers (such as those found in high school history classes) tend to focus only on the twodimensional surface features of an issue. Experts incorporate an abstract third dimension, broader conceptual structures that help them organize and analyze data in order to reason through a problem (Spiro, Collins, \& Thota, 2003; Spiro \& Jehng, 1990). Many times, novice learners tend to examine social problems superficially, and fail to put in the time and effort necessary to grapple with the depth and complexity of an issue (VanSickle \& Hoge, 1991; Wineburg, 1991).

To develop persuasive and reasonable potential solutions to historical problems, learners must be able to critically examine conflicting perspectives and weigh the plausibility of various problem solutions. This requires learners to remain engaged in the problem for an extensive period of time, to demonstrate historical empathy, and to move 
towards an evaluative epistemology (Kuhn, 1999, 2005; Parker, Mueller, \& Wendling, 1989; Saye $\&$ Brush, 1999, 2002). Each of these criteria is discussed in greater detail here.

\section{Engagement with the Problem}

Developing the expertise required for disciplined inquiry into the past requires sustained, focused effort to develop a deep understanding of the historical period being studied. Teachers have often been unsuccessful in motivating students to persist with exploration of the topic to develop deep knowledge (Newmann, 1991; Onosko, 1991; Rossi, 1995). Because they do not find history relevant or engaging, students resist the sustained study of a topic.

Studies examining methods for increasing engagement suggest that learners must perceive intrinsic worth and purpose in the task they are asked to undertake in order to maintain the effort required to develop deep knowledge of a subject (Newmann, Wehlage, \& Lamborn, 1992). More authentic tasks such as those that pose problems similar to the problems encountered in the real world may promote deeper levels of student engagement (Brown, Collins, \& Duguid, 1989; Gordon, 1998; Newmann \& Associates, 1996; VanSickle \& Hoge, 1991).

\section{Historical Empathy}

To fully grasp complex historical problems, learners must also be able to account for and understand competing perspectives regarding an historical topic. This understanding involves engaging in and demonstrating empathy - the ability to view the world from the perspective of another (Newmann, 1991; Parker et al., 1989). However, historical empathy goes beyond this general definition. Historical empathy requires learners to genuinely entertain the perspectives, beliefs, and values of those who are distant from the learner in time or cultural space (Ashby \& Lee, 1987; Barton \& Levstik, 2004). It requires not only a disposition and willingness to entertain these beliefs, but a substantial amount of historical knowledge to be able to understand the context in which historical figures lived (Ashby \& Lee, 1987; Yeager \& Foster, 2001).

Barton and Levstik (2004) identified two aspects of historical empathy: perspective taking and caring. Historical empathy as perspective taking involves learners having the ability to utilize the perspectives of people in the past to help explain past events. This approach requires learners to "understand, as best [we] can, their world and how they saw it no matter how greatly those differences and perceptions differed from our own" (Barton \& Levstik, 2004, p. 208). Perspective taking is additionally challenging for novice history students because various individuals and groups in the past most likely held different views of what occurred at that time. In order to be able to weigh these competing perspectives, expert historians employ the skills of contextualization, corroboration, and sourcing (Barton \& Levstik, 2004; Spoehr \& Spoehr, 1994; Wineburg, 1991).

- volume 2 , no. 1 
These skills generally have not been mastered by high school history students (VanSledright, 2002; Wineburg, 1991).

Historical empathy as caring involves learners making an emotional connection with individuals and events in the past, either by caring about what occurred in the past, caring that specific events in the past actually took place, or caring for individuals in the past and their circumstances (Barton \& Levstik, 2004). Barton and Levstik argued that perspective taking and caring are interrelated:asking students to engage in perspective taking when they don't care about the topic they are studying or care for the individuals from the past they are examining does not promote historical empathy. The concepts of historical empathy as caring and engagement are also related. One could argue that learners must be engaged in the topic under study in order to demonstrate both caring and perspective taking.

\section{Evaluative Epistemology}

A learner's ability to think historically begins with the way they perceive history. Novices tend to view history as a straightforward recounting of events, and regard historical texts as authoritative narratives (VanSledright, 2002; Wineburg, 1991). In contrast, expert historians view historical texts as individuals' interpretations of an event, and can look beyond the written text for subtexts that allow them to evaluate the arguments and evidence put forward by the author of the narrative (Holt, 1990). Before novices can engage in historical thinking they must perceive knowledge as uncertain and constructed by the knower. Only then can they view historical texts as claims and develop the nuances of historical thinking necessary to weigh those claims. When novice learners view historical texts as authoritative accounts, they do not anticipate the possibility of subtexts. Thus, they are unable to employ a critical aspect of historical thinking.

Kuhn (2005) theorized that critical thinking evolves developmentally. Learners move from assumptions that knowledge is certain and received from authoritative sources to beliefs that knowledge is uncertain and constructed by the knower. At a more advanced developmental level, learners begin to move toward a multiplist perspective in which they view knowledge as subjective opinions. However, at the most advanced level, learners assume an evaluative view in which assertions may be compared and judged by the quality of evidence used to support them. At this level, learners engage in critical reasoning in order to rigorously weigh alternative points of view to make an informed decision about a historical event.

\section{Multimedia Learning Environments to Support Problem-based Inquiry}

Theorists have claimed that authentic problem-based learning experiences may produce greater student engagement with content (Choi \& Hannafin, 1995; Hmelo-Silver, 
2004; Newmann, Wehlage, \& Lamborn, 1992). Some researchers have suggested that rich, authentic contexts that can be facilitated by multimedia learning environments encourage students to become engaged with the content, explore more deeply, and develop more complex views of issues (Dwyer, 1994; CTGV, 1992; Kinzie \& Sullivan, 1989; Pedersen \& Liu, 2003). In addition, tools and resources available in multimedia learning environments may be used to help scaffold disciplined inquiry into ill-structured problems (Hannafin, Land, \& Oliver, 1999; Hmelo-Silver, 2006; Jacobsen, Maouiri, Mishra, \& Kolar, 1996; Land \& Zembal-Saul, 2003; Masterman \& Rogers, 2002; Reiser, 2004). Research examining methods to support students' historical problem solving suggests that scaffolding that is integrated into hypermedia learning environments may improve conceptual representations of knowledge and analytical rigor (Hynd, Hubbard, Holschuh, Reinking, \& Jacobsen, 2000; Perfetti, Britt, Van Dyke, \& Gabrys, 1999; Spoehr \& Spoehr, 1994).

Findings from the initial studies in our present line of inquiry support such claims. When compared to peers who encountered the topic in a more traditional expository classroom setting, students who studied an historical event using a problem-based multimedia-enhanced learning environment demonstrated greater engagement with the content and more empathetic understandings of historical dilemmas (Brush \& Saye, 2000; Saye \& Brush, 2002, 1999). Also, our initial research has suggested that conceptual and strategic scaffolds embedded within a multimedia learning environment may assist students with analyzing historical data and synthesizing the data in order to develop more advanced views of historical events (Brush \& Saye, 2001; Saye \& Brush, 2002).

\section{Purpose of Study}

This study extends our previous research in order to discover whether multimedia resources and scaffolding might be combined with other structures to support student engagement and historical empathy during a problem-based activity in history. In our previous research (e.g., Brush \& Saye, 2000, 2001; Saye \& Brush, 1999, 2002), we worked with a teacher who had limited experience implementing problem-based inquiry in her classroom. We used the results from these field studies to refine the overall problembased unit, redesign some of the scaffolds used to facilitate information gathering and synthesis, and design new scaffolds to assist students with the challenges faced when constructing, presenting, and defending a persuasive argument related to a historical problem. For a more detailed accounting of the design modifications made to the overall problem-based unit prior to the implementation in this study, please refer to Saye and Brush (in press).

In the current study, we collaborated with two teachers who were more experienced in facilitating problem-based inquiry activities with their students than the teacher we

- volume 2 , no. 1 
worked with in our previous research. We wanted to examine the effectiveness of our modifications to the overall learning environment-particularly with teachers who expressed more comfort in implementing problem-based inquiry, and with a larger population of students. In addition, unlike our previous studies, we wanted to examine the impact problem-based inquiry activities had on students' ability to engage in the two facets of historical empathy (perspective taking and caring), and their epistemic assumptions about history. Specifically, we sought to (1) determine whether multimedia-supported problem-based inquiry activities encouraged learners' deep engagement with an historical problem, (2) determine whether multimedia-supported inquiry activities facilitated students' acquisition of historical empathy and recognition of competing perspectives regarding an historical problem, and (3) explore how structured inquiry activities and scaffolds embedded within multimedia learning environments affected students' epistemic assumptions about history.

\section{Method}

\section{Participants and Setting}

Participants included 45 students in two 11th grade history classes. The classes were required of all high school students. Two veteran social studies teachers with experience in problem-based historical inquiry were recruited to implement the problem-based unit in their classrooms.

Tim (pseudonym) had taught for nine years. He regularly served as a mentor teacher for preservice social studies teachers enrolled in field experience activities associated with their certification programs. Tim had also previously worked with one of the researchers on a demonstration project for PBI social studies curricula. Tim taught the problem-based unit to an intact class of 26 students (13 boys and 13 girls) enrolled in general level 11th grade U.S. history. He judged the students in his class to be fairly representative of a typical 11 th grade classes at his school.

Craig (pseudonym) was a four-year teaching veteran. He had graduated from the undergraduate and master's programs coordinated by one of the researchers, and integrated PBI activities into his curriculum several times each year. Craig's class featured a mixture of 20 juniors and seniors (11 boys, 9 girls) taking a social studies course designed for students who had not passed the state-mandated graduation exam in U.S. history.

Both Tim and Craig's schools were situated in small southeastern cities. However, there were some differences between the two settings. Tim's school was in a city in which a large land-grant university was located. Craig's school was situated in a bluecollar industrial town. Student enrollments at the two schools were similar (1,255 at Tim's 
school and 1,365 at Craig's school), as were the ethnic compositions of the schools (68\% white, 28\% black, and 4\% Asian at Tim's school; 66\% white and 32\% black at Craig's school). The diversity of Tim's class was similar to that of his school (69\% white and $27 \%$ black). Craig's class, however, had a higher percentage of African-American students $(60 \%)$ than that of the general school population.

\section{The Decision Point! Multimedia Environment}

Decision Point! (DP) Civil Rights is an integrated set of multimedia tools for exploring and presenting social studies content (Saye \& Brush, 2004). DP includes two basic components: an interactive database of multimedia content resources related to the civil rights movement and scaffolding tools to support collecting, analyzing, and evaluating historical evidence and presenting conclusions. The database is organized conceptually into three strands that represent the principal change strategies employed by the movement: legal challenges, nonviolent protest, and Black Power. Within each strand are seven to eight events associated with that strategy. Each event features an introductory essay, a timeline, and a number of associated documents. Featured documents include primary and secondary text, images, audio, and audiovisual media (see Figure 1).

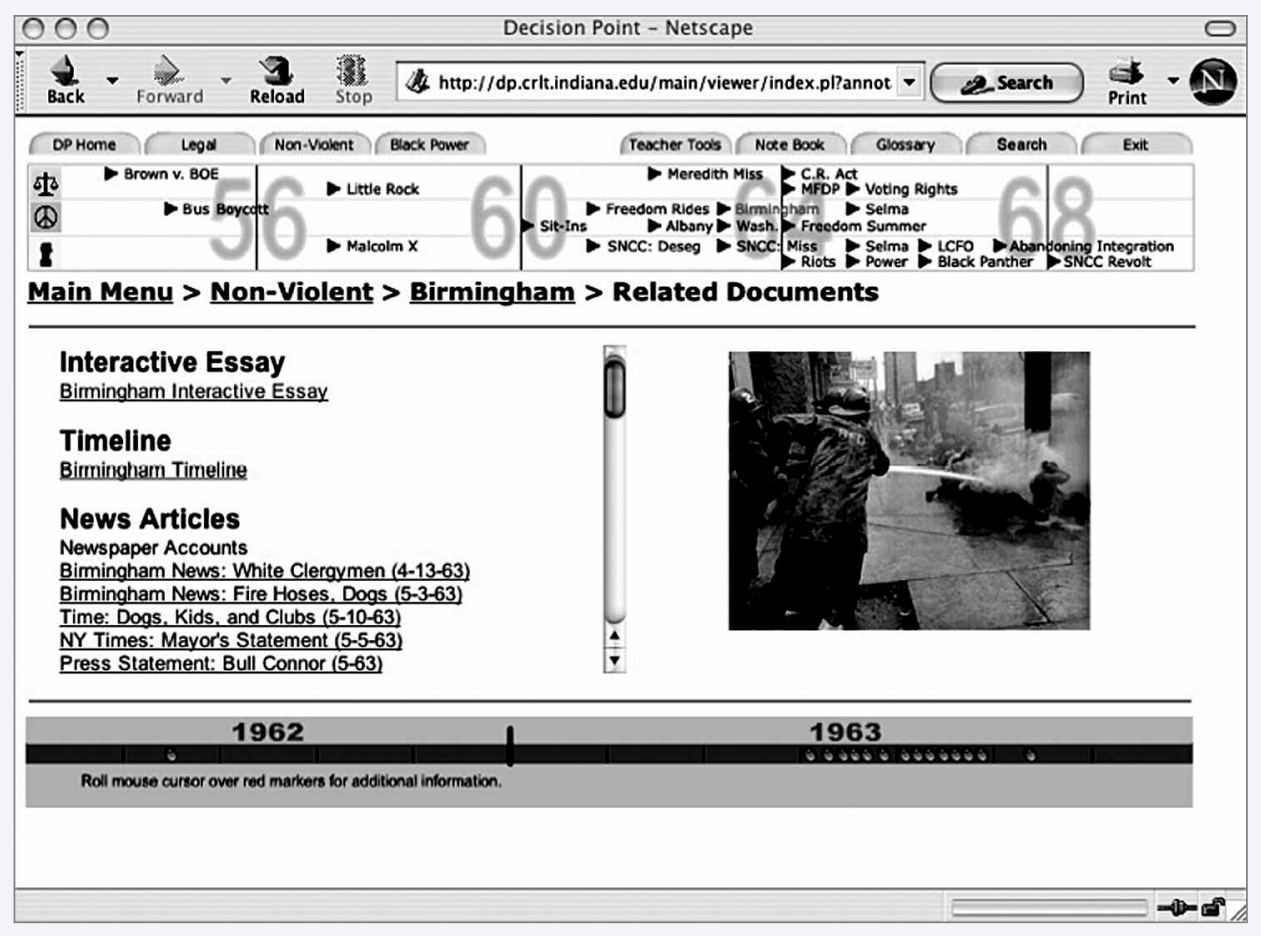

Figure 1. The DP environment 
Scaffolds embedded in DP. Within the DP environment, we embedded a variety of scaffolds to assist students in determining what data to consider when solving a problem, monitoring and regulating their progress, and considering alternative solutions to the unit problem (Brush \& Saye, 2001). These scaffolds are described here:

Interactive essays. Each of the events within the DP database contains a hyperlinked "interactive" essay that provides students with a conceptual scaffold for that event (Hannafin et al., 1999). To extend the integration of the interactive essay with the other documents in the database, hyperlinks are embedded in the essay linking specific contextual areas of the essay with specific primary documents. Refer to Figure 2 for an example of an interactive essay linked to a primary document.

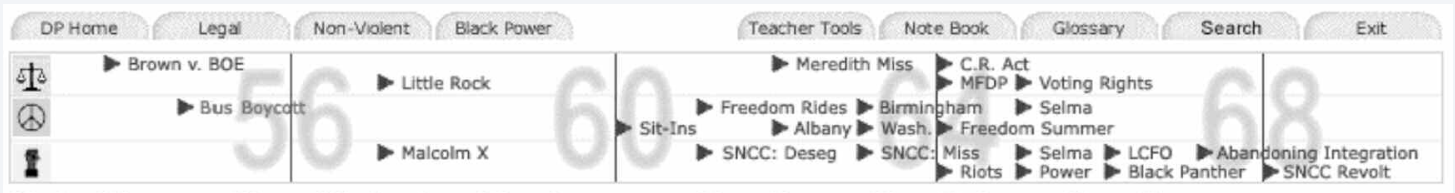

Main Menu > Non-Violent $>$ Montgomery Bus Boycott $>$ Interactive Essay

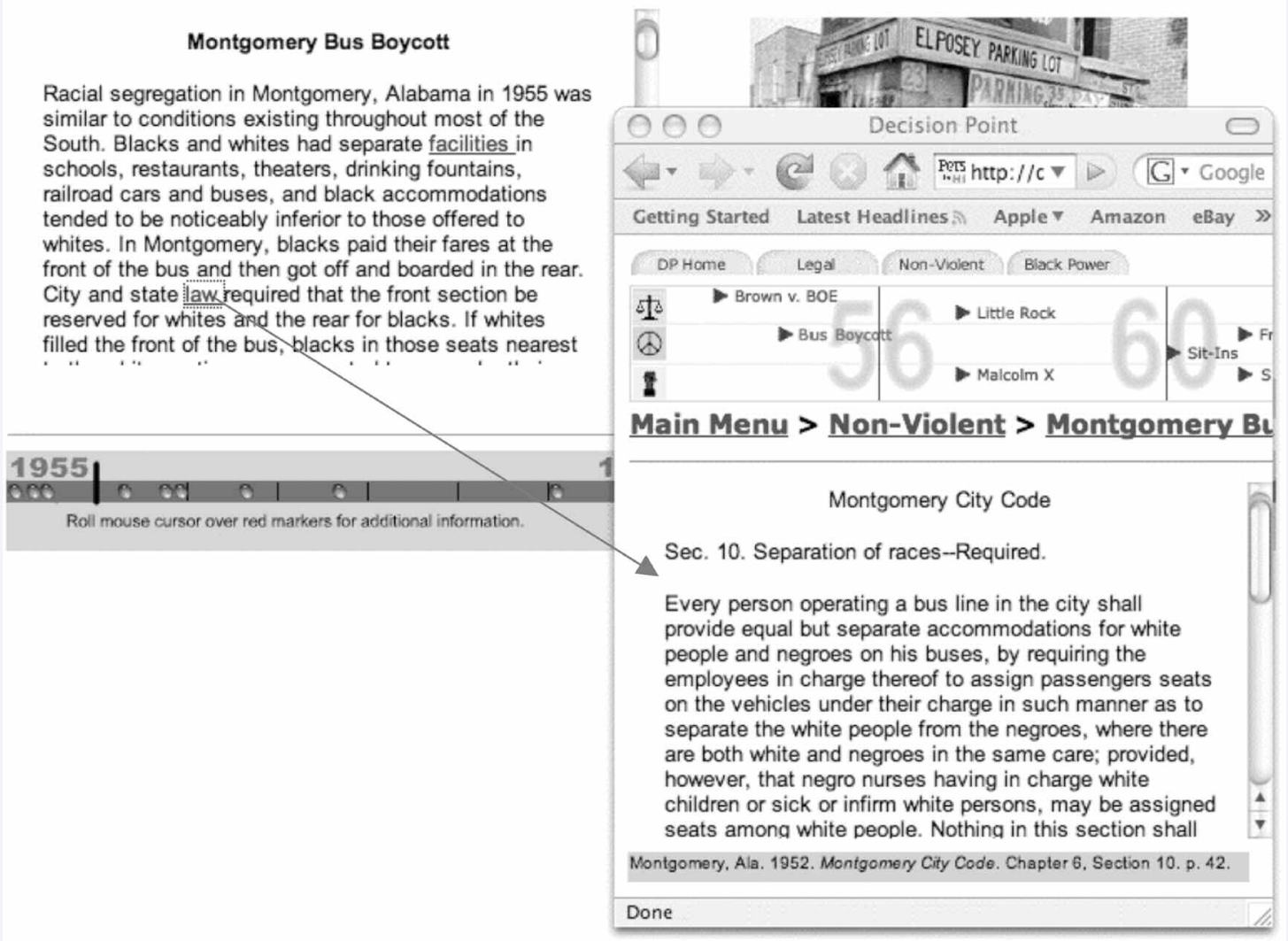

Figure 2. Interactive essay linked to primary document. 
In the example in Figure 2, students exploring information related to the Montgomery Bus Boycott could begin by accessing the interactive essay for the event within the DP database. The hyperlinks embedded within the interactive essay would allow students to view supporting primary and secondary sources relevant to the event-in this case, the actual Montgomery city law that dictated separate accommodations for white and black passengers on city buses.

Student guides. The "guides" section of the DP environment offered conceptual scaffolds by providing data analysis categories similar to those that an historian might use to organize and synthesize evidence about an event (see Figure 3). Two forms of guides were generally used by students. The event analysis guides provided students with a broad scaffold designed to assist them with making sense of the overall event they were assigned to research (e.g., desegregation efforts in Birmingham). The document analysis guides were designed to assist students with analyzing specific primary sources relevant to the event they were researching (e.g., King's Letter from a Birmingham Jail).

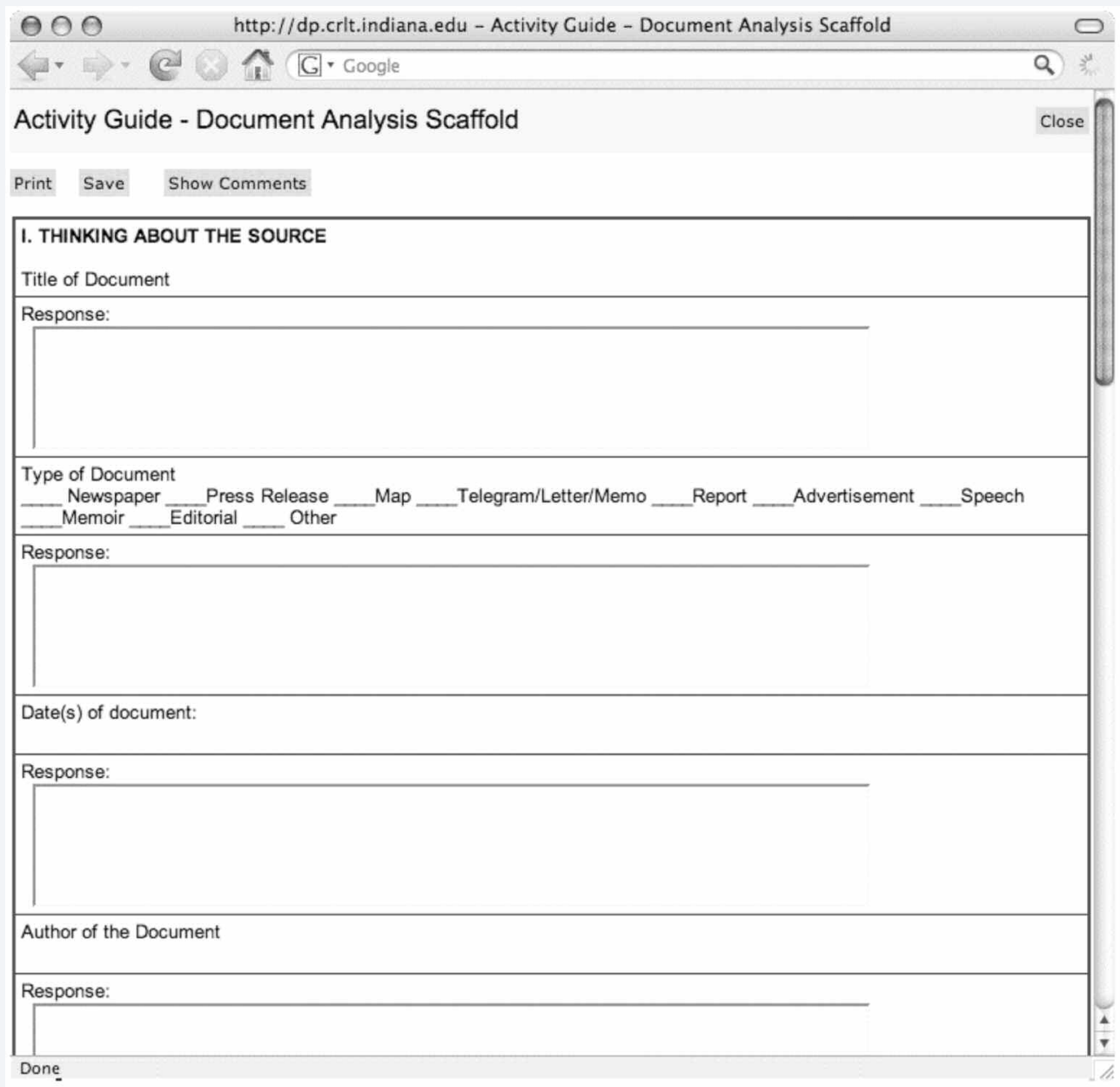

Figure 3. Document analysis guide.

- volume 2 , no. 1 
Storyboard template. We developed a storyboarding process to assist students with planning the scope and sequence of their presentations. Groups used a five-page template that corresponded to the sequence they were expected to follow in developing and delivering their presentations (see Figure 4). This sequence included a description of the group they were representing, an overview of the problem, a summary of the proposed strategy to solve the problem, a list of arguments for the strategy, and a list of arguments against the strategy.

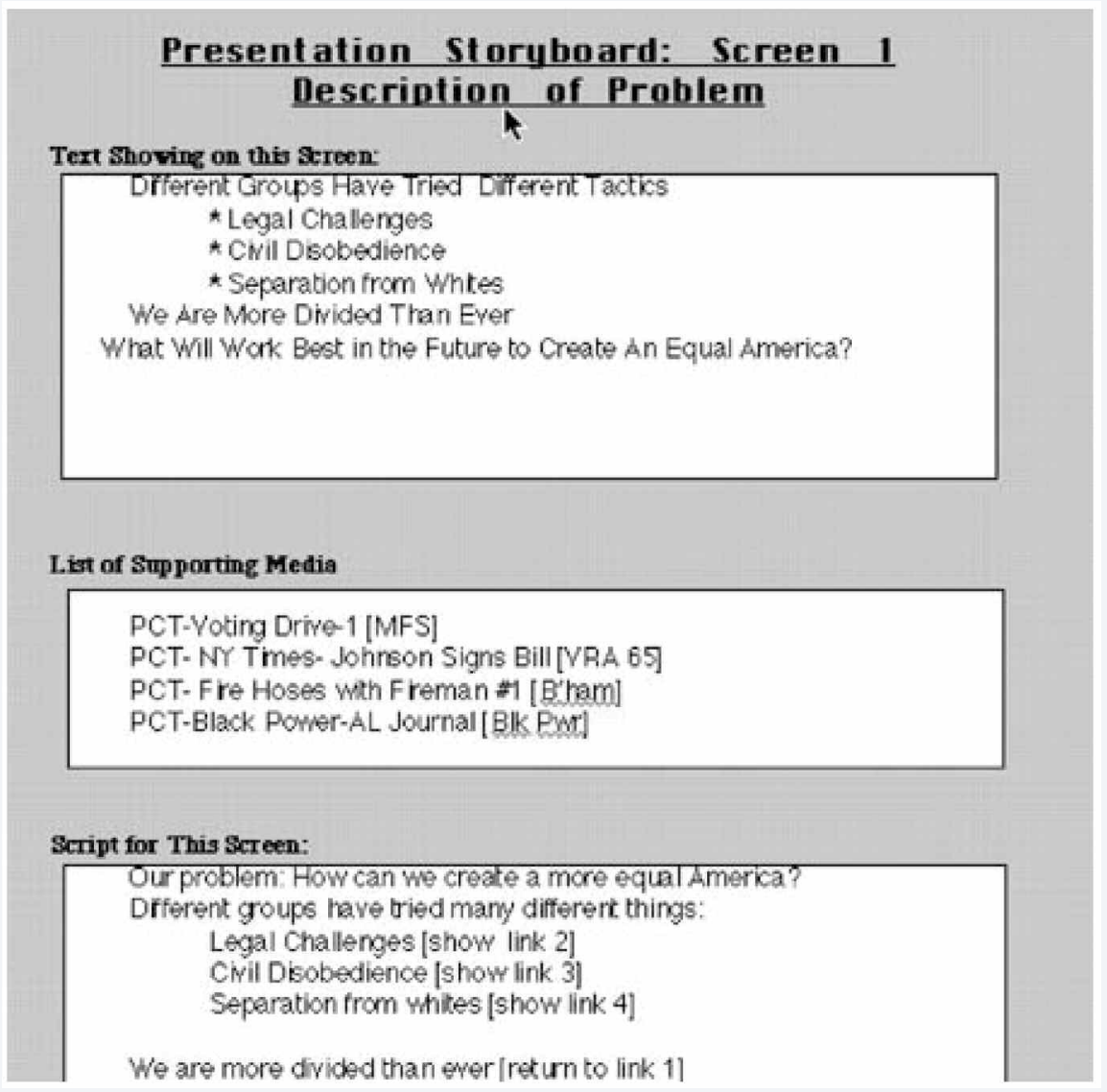

Figure 4. Sample storyboard template.

Presentation tool. A student presentation tool integrated within DP provided a predefined structure for the presentation and tools, and allowed students to link supporting multimedia evidence from the database to help support their arguments (see Figure 5). This tool provided a scaffold for a persuasive presentation, 
in which students were required to develop an argument in support of a strategy they were advocating and provide primary-source evidence to support their argument.

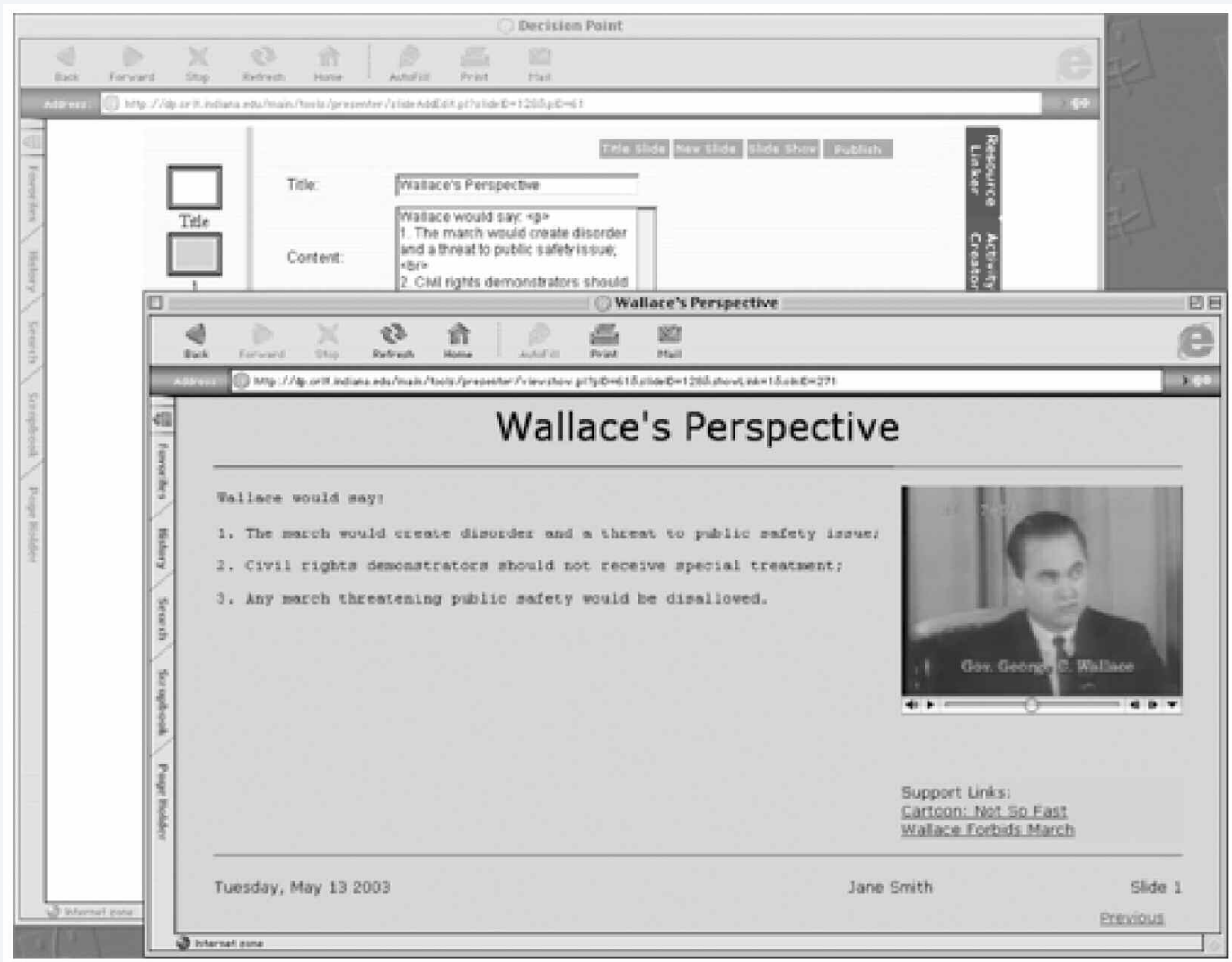

Figure 4. The DP student presentation tool.

\section{Overview of the Decision Point! Problem-based Unit}

Gordon (1998) argued that hypothetical challenges or "scenario-based problems" that place students in realistic roles may be considered as authentic problems. In our problem-based inquiry model, students are not asked to solve a problem for which exists a "correct" answer. In contrast, our approach provides students with a persistent, illstructured problem that most likely will not be "solved" to the satisfaction of all participants. We purposefully select historical problems in which various stakeholder groups disagreed about the proper course of action, and in which the problem was generally not resolved during the time period being explored. We consider these problems to be truly authentic because they persistently recur in different contexts throughout history (Saye \& Brush, 2004). 
The problem-based scenario used in this study placed students in the roles of consultants to civil rights leaders immediately following the assassination of M. L. King, Jr. in 1968. Student teams answered the unit problem: What strategies should be pursued in 1968 to continue the struggle for a more just, equal society? Each team used the DP database and tools to explore specific movement events during 1954-1968. After researching their assigned events, members of the research teams re-formed into new decision-making teams and used the information they gathered to develop arguments to support the best course of action to address the central unit problem. Each group then constructed a multimedia presentation designed to persuade the audience that their solution to the problems was the most appropriate.

Each of the teachers began the unit by introducing the purpose of the unit and the overarching unit problem. They then presented an introduction to the civil rights movement as a social phenomenon. Once the introduction was completed, the teachers divided students into three-student data gathering groups. The researchers allowed the teachers to use their own judgment in forming the students groups; thus, the researchers provided no input toward the makeup of the groups. Each of the groups was assigned two specific events within the database (e.g., "Birmingham" and "Albany"). The assigned events represented two pivotal episodes within a particular change strategy strand. Each group used the "guide" scaffolds available in DP to collect data relevant to their two assigned events. Students were given two class sessions to complete data gathering activities.

Once students completed their data gathering, the teacher combined the groups to form five-student expert presentations groups. Each group was required to assume the role of "consultant" to a specific activist group or organization: the U.S. government, the Southern Christian Leadership Conference (SCLC), the Mississippi Freedom Democratic Party (MFDP), the Black Panthers/Separatists, or the Student Nonviolent Coordinating Committee (SNCC). These groups were required to utilize the data they had collected in the previous activity in order to develop multimedia presentations that provided persuasive arguments for the predominant change strategy advocated by the organization they were representing. As with previous groups, each presentation group had access to a computer with the DP environment.

The presentation groups were given four class sessions to plan for and create their presentations. Groups were required to use the storyboard template to plan their presentations, and then receive approval from their teacher prior to creating their presentations using the DP presentation tool. On the final three days of the unit, each group gave its presentation to the class and defended the strategy they were advocating. Students representing other groups were allowed to question and challenge strategies that they believed conflicted with the strategy they advocated. 
Table 1 provides a summary of the unit problem and scaffolds that support students in addressing the problem.

Table 1

Summary of DP: Civil Rights unit problem and supporting scaffolds.

\begin{tabular}{|c|c|}
\hline Student Tasks & Supporting Scaffolds \\
\hline $\begin{array}{l}\text { Task 1: Data Gathering for } \\
\text { Two Civil Rights Events } \\
\text { (Day 1-Day 3) }\end{array}$ & $\begin{array}{l}\text { - Interactive essays hyperlinked } \\
\text { to primary-source documents } \\
\text { - Event analysis and document } \\
\text { analysis guides }\end{array}$ \\
\hline $\begin{array}{l}\text { Task 2: Synthesize Event Data } \\
\text { and Plan Presentations } \\
\text { (Day 4-Day 5) }\end{array}$ & $\begin{array}{l}\text { - Event analysis and document } \\
\text { analysis guides } \\
\text { - Storyboard template }\end{array}$ \\
\hline $\begin{array}{l}\text { Task 3: Construction of Presentation } \\
\text { (Day 6-Day 7) }\end{array}$ & $\begin{array}{l}\text { - Storyboard template } \\
\text { - Online presentation tool }\end{array}$ \\
\hline $\begin{array}{l}\text { Task 4: Present and Defend Conclusions } \\
\text { (Day 8-Day 10) }\end{array}$ & $\begin{array}{l}\text { - Online presentation tool/database } \\
\text { resources }\end{array}$ \\
\hline
\end{tabular}

\section{Design and Data Sources}

Our line of research can best be described as design-based research (Brown, 1992; Cobb, Confrey, diSessa, Lehrer, \& Schauble, 2003; Collins, Joseph, \& Bielaczyc, 2004; Wang \& Hannafin, 2005). Design-based research is "a systematic but flexible methodology aimed to improve educational practices through iterative analysis, design, development, and implementation, based on collaboration among researchers and practitioners in realworld settings" (Wang \& Hannafin, 2005, pp. 6-7). Design-based research views innovative teaching as an experiment occurring in the "multiply confounded" world of real classrooms rather than controlled environments. From this perspective, innovative educational environments and activities may be simultaneously designed, implemented, and studied.

In design-based research, researchers generally utilize multiple data sources and data collection methods (Wang \& Hannafin, 2005). This study employed a qualitative methodology with data that included classroom observations, culminating student presentations and the class discussions that took place after the presentations, and teacher and student interviews.

- volume 2 , no. 1 
Classroom observations and student presentations. All classroom activities were observed and videotaped in the two classes (a total of 15 hours for each of the classes). Observations focused on student interactions with the technology and embedded scaffolds, student questions/discussions with the teacher and their peers, and students' management strategies for completing the problem-based unit. In addition, all culminating group presentations and subsequent class discussions were videotaped. These data were used to determine evidence of engagement and historical empathy exhibited by students.

Student interviews. The researchers asked each of the teachers to solicit volunteers to participate in semistructured exit interviews. Six students from each class were selected from the group of volunteers (six boys and six girls; 12 students total). Although only students who volunteered to be interviewed were included in the potential interviewee pool, final selection criteria for the students attempted to maximize diversity in gender, ethnicity, and course GPA. In terms of ethnicity, six of the students interviewed were white, five students were African-American, and one student was Hispanic. These students participated in 30-minute interviews conducted by the researchers. Interviews were audiotaped and transcribed. Questions solicited students' evaluations of the strengths and weaknesses of the DP unit activities, scaffolds, and the ways the activities and scaffolds affected their learning experiences.

Teacher interviews. The two participating teachers (Craig and Tim) also took part in post-unit semistructured interviews. The interview sought their perceptions about the strengths and weaknesses of the unit and any effects that the changes had on student learning and the classroom environment. Each teacher interview lasted approximately 45 minutes and was audiotaped and transcribed.

\section{Procedure}

As outlined earlier, the civil rights unit was designed to last for 10 class sessions. Each class period lasted approximately 90 minutes. The researchers independently observed each classroom session but did not interact with the teachers or students during classtime. In addition, each of the class sessions was videotaped. Approximately one week after the end of the unit, one of the researchers conducted the post-unit student and teacher interviews. All interviews were audiotaped.

\section{Data Analysis}

Data analysis methods included typological analysis (in which a general rule or standard is used to divide data into groups for analysis), analytic induction, and content analysis (Goetz \& LeCompte, 1984). All classroom observation, group presentation and discussion, teacher interview, and student interview data were transcribed by the researchers. 
Each of these data sets was reviewed by the researchers in order to identify emerging themes and constructs (Miles \& Huberman, 1994), and to match these themes with the overall research questions. In our initial examination of study data, we consciously sought to group data based on the questions we asked about the effects of multimediasupported inquiry activities on student engagement, historical empathy, and epistemic assumptions about history

In analyzing the data for evidence of engagement, we used Newmann, Whelage, and Lamborn's (1992) definition of engagement as "the student's psychological investment in and effort directed toward learning, understanding, and mastering the knowledge, skills, or crafts that academic work is intended to promote" (p. 12). In this framework, engagement can be determined by examining students' levels of participation in classroom activities, their enthusiasm and interest expressed in tasks, and the degree of care students demonstrate in completing the tasks assigned to them (Newmann et al., 1992).

In terms of historical empathy, we based our analysis on Barton and Levstik's (2004) dual aspects of historical empathy: perspective taking and caring. Thus, we examined the data for evidence of students' ability to utilize the perspectives of people in the past to help explain past events, and their willingness to make an emotional, personal connection with individuals in the past and to consider the human consequences of past actions and events.

Finally, we framed our analysis of students' epistemological assumptions based on Kuhn's (2005) three epistemic levels: absolutist, multiplist, and evaluative. At the absolutist level, students assume that knowledge is certain and received from authoritative sources. At the multiplist level, students shift to the belief that all knowledge is uncertain and subject to opinion. At the evaluative level, students begin to examine assertions based on the quality of evidence used to support them.

Using content analysis techniques, each data source (observations, presentations/ discussions, teacher interviews, student interviews) was independently analyzed by the two researchers using the operational definitions of the three areas of inquiry as deductive categories. After the independent analyses of each source were completed, the researchers compared their results and noted areas of discrepancy in the coding of the data set. Each discrepancy was discussed and resolved in order to obtain agreement of 100 percent. The researchers then repeated this analysis procedure for each subsequent data source.

Reliability, validity, and bias. Several methods were used to enhance the reliability and validity of the data collection and analysis procedures employed in this study, and to reduce the potential for researcher bias. First, both data source and investigator triangulation were used to strengthen the validation of the themes emerging from the data (Denzin, 1989; Yin, 2003). In terms of data source triangulation, multiple data were collected for this study from multiple settings (two schools with different demographics)

- volume 2 , no. 1 
and analyzed independently (Enyedy, 2003). This approach provided several opportunities to examine the accuracy of the data, and minimized threats of drawing inferences based on individual data sources. In terms of investigator triangulation, the two researchers independently analyzed the data sources in order to corroborate the themes and conclusions drawn from those analyses and to reduce the potential for researcher bias. Second, the researchers employed member check with the teachers involved in the study in order to ensure that their views (particularly those drawn from teacher interviews and classroom observation data) were interpreted accurately (Stake, 1995).

\section{Results and Discussion}

As stated previously, this study sought to (1) determine if multimedia-supported problembased inquiry activities encouraged learners' deep engagement with an historical problem, (2) determine whether multimedia-supported inquiry activities facilitated learners' acquisition of historical empathy and recognition of competing perspectives regarding an historical problem, and (3) explore how structured inquiry activities and scaffolds embedded within multimedia learning environments affected students' epistemic assumptions about history. Findings related to each of these areas are discussed here.

\section{Student Engagement with the Problem}

Analysis of interview and classroom observation data suggested that students participating in the DP unit appeared to be highly engaged with the central problem as measured by their participation in classroom activities and their enthusiasm in contributing the assigned tasks for the unit (Newmann et al., 1992), and maintained that engagement throughout the unit. Student interview data indicated that students believed that their experiences with the multimedia resources positively affected their level of engagement with the historical content. For example, when asked what was different about this unit, one student stated, "We got to see like actual footage of things that are going on right now, I mean we could've watched the video of all of it. I think it was a lot more interesting to have those little clips we could look at and just actually see, like half of it." When asked what he thought was important about the unit, another student said, "It changed [my views] because we got to look at people's, like, views on like what's happening. Not just reading about what happened. We got to see people's opinion on it and how everyone had a different, like, perspective of what went on." Another student stated "that [the media] really makes you think, I mean, put yourself in what happened back then compared to now. I see how much things have changed throughout history, that makes history fun." 
Students' dialogue during their discussions that followed the group presentations also suggested a high level of engagement. In the following dialogue, a group representing the MFDP was arguing that the federal government wasn't involved enough, and the teacher pointed out that there might be other factors that influenced the effectiveness of the federal government:

Tim: "What, then, is the major problem with the federal government trying to enforce law?"

S1: "Well, they didn't enforce it enough because they were afraid that people would stop voting for them ..."

Tim: "Well, but there you're right, but who's resisting this change most, class?"

S1: "The government."

Tim: "State governments are. It's hard to get something done at the federal level if the states are so resistant, most definitely. So they were fighting those kinds of episodes and I think that's why the federal government was slow to get some things accomplished."

Tim: "Other questions for this group?"

[Pause]

S1: "But you also saw, in Little Rock, how well it worked. Those kids got to school all right ..."

In this example, Tim was pointing out that mitigating circumstances may have related to the lack of effectiveness of the federal government in certain situations. However, even after Tim let the group "off the hook" by asking for questions from the audience, group members persisted with a discussion about ideas that they were able to support with factual evidence from the period under study. Such persistence suggests authentic engagement with thinking about historical issues. The students were interested in the problem not because the teacher directed them to discuss it; they were genuinely entertaining the issue.

The teachers implementing the unit also believed that the multimedia available in the DP database facilitated student engagement in the topic. Tim commented, "Decision Point, I thought was great because it's multimedia at its best. There were speeches, there were songs of the time, there were newspaper articles, magazine articles, there was, of course the interactive essays and then they were getting to put that together in a multimedia presentation, which is what they like to do. And I never saw a time when I didn't think that they were not involved. I thought they were always engaged." Craig 
stated that the structure of the overall problem-based unit may have had a positive impact on students who had typically demonstrated a lack of interest in history. He said, "I'm thinking of two students in particular ... they were more engaged in the content and I think that shows when we started getting into the slides and the music and even the documents and discussions and the small group discussions I noticed they were more attentive." Craig continued by describing the differences he observed in the two students:

One Malcolm X student was not very motivated in the past, didn't have a lot of skills, didn't exhibit a great interest for school at all, but really took this project and ran with it. He just loved it. He showed that genuine interest and was doing his work without having to have any prompting by me, which was unusual. And the Black Panther group, that student, he would sleep, show up late, sometimes wouldn't come ... chronic absenteeism, but he was there every day. Their presentation was one that I wasn't expecting to be outstanding, and it really was. I think overall it was a good presentation, but for them it was tremendous.

Data also demonstrated that students may have been able to effectively engage in dialogue with their peers and use artifacts available in the DP database to debate competing perspectives regarding civil rights issues. In the following excerpt from a culminating presentation, a group representing the SCLC was discussing the Albany movement and the effectiveness of the SCLC's strategies. Craig challenged the group's interpretation of those strategies, and when group members had difficulty generating different potential solutions to the problem posed to them, a student from the audience provided an alternative interpretation for the class to consider:

Craig: "Why would a white police officer bail out Dr. King?"

S1: "I don't know why the whites would ... because he liked blacks and he wanted Dr. King to keep protesting 'cause he believes in what he's saying?"

Craig: "That's a possibility, [S2] what do you think?"

S2: "He probably felt that what the whites were doing to the blacks was wrong." Craig: "You think this white police officer had a conscience. He said, 'You know what, Dr. King is a good man, he's doing the right thing trying to get voting rights for people, trying to get civil rights, he doesn't belong in jail, I'm going to have him out so he can do more good.' But Dr. King himself wanted to stay in jail, so if he wanted to help Dr. King and his movement it would make sense that someone who liked Dr. King would do what Dr. King wanted ... so why, why would 
someone want him out of jail? ... How about anybody in the audience, does anyone have a thought on that?"

S3: "Because he wanted, I guess like, Martin Luther King wanted to prove a point, I guess, if he didn't like Martin Luther King he'd bail him out just so he couldn't prove his point."

Craig: "Say that again, I don't think everyone heard it."

S3: "I said that I think he'd bail Martin Luther King out so that Martin Luther King couldn't prove his point. Martin Luther King wanted to stay in jail to prove the point that he would do whatever it takes to get civil rights and he gone ahead and got him out so he couldn't prove his point ..."

Craig: "I think that's a possibility, we have two different ends of the perspective to think of ..."

Here, Craig used the question-and-answer session of the group presentation to critically examine an historical event and weigh competing (and equally plausible) interpretations of an occurrence. In this case, the SCLC group asserted that Martin Luther King was bailed out of jail in Albany by a sympathetic white police officer because "what the whites were doing to the blacks was wrong." The format of the culminating presentations potentially allowed other students to engage in critical examination of the evidence provided and provide alternative interpretations of the historical events presented.

In a similar example from Craig's class, a group of students used a political cartoon from a Montgomery, Alabama, newspaper to argue that self-defense advocated by the Black Panthers was not an effective means to bring about social change. The cartoon depicted a figure representing the Black Panthers and a figure representing the $\mathrm{Ku}$ Klux Klan pointing at each other through a mirror. However, a student in the audience debated the group's interpretation of the message presented in the cartoon:

Craig: "What have we got here?"

S1 [presenter]: "It's showing that they're both [Black Panthers and KKK] looking kind of the same. It's a cartoon."

Craig: "So, what's this about?"

S2 [presenter]: "It's showing the, trying to show the strong similarities between the two groups."

S3 [presenter]: "They're both using violence to get their way."

- volume 2 , no. 1 
S4 [audience member]: "You don't see the difference?"

S3: "Hmmm?"

S4: "I mean, the KKK, they're the ones who started the violence. The other group, they were just protecting themselves. That's the big difference."

In this example, the student audience member took issue with the presenters' analysis that the KKK and the Black Panthers were using similar tactics. He was able to analyze the message presented in the cartoon and effectively discuss how the cartoon may have misrepresented the position of the Black Panthers. In addition, the student was able to apply knowledge of the period to assess the validity of arguments made in an historical artifact of the period. In both of the examples from Craig's class provided here, one could argue that if the students were not actively engaged in analysis of the position presented by their classmates, they would not have been willing (or able) to analyze the historical artifact and provide a valid criticism of their peers' use of that artifact to support their positions.

In both of the examples, however, historians might argue that students could have strengthened their arguments by discussing the sources of the artifacts and the potential bias inherent in those sources. For example, the cartoon the students were analyzing was printed in the Alabama Journal, a newspaper published in Montgomery, Alabama. Ideally, students examining the cartoon would have interrogated the source, noted that it was from the Alabama Journal, and discussed the motivation for a white Alabama newspaper trying to discredit the Black Panther movement. The student's discussion of the artifact did not provide evidence that he had reached that level of complexity in his ability to weigh the perspective or bias of the source. This situation demonstrates the continued challenge of moving students beyond interest and engagement with a problem toward the application of critical thinking skills to analyze, interpret, and corroborate historical artifacts (Wineburg, 1999, 1991).

\section{Historical Empathy: Caring and Recognition of Competing Perspectives}

Analysis of classroom observation, interview, and presentation/discussion data provided some evidence that students demonstrated both historical empathy as perspective taking and historical empathy as caring during the problem-based unit activities. The degree of student empathy for the perspectives of historical figures was suggested by the fact that many of the student groups actively maintained the roles assigned to them for their presentations throughout post-presentation discussions, and used those perspectives when explaining the course of action they promoted (Barton \& Levstik, 2004). The following is an excerpt of a 10-minute dialogue among students that occurred after one group (students S2, S4, and S5), representing the black separatists' view, presented 
a rationale for African Americans to defend themselves from violence committed against them. Other students in the class took issue with the idea of "self-defense" against violence:

S1: "I'm not sure I understand what you're talking about self-defense for if you're gonna say that, if you're gonna go ..."

S2: "That's self-defense ..."

S1: "No it's not self-defense, man! I mean, if they went and attacked a bunch of people ..."

S2: “We're saying if ... someone's attacking me I'm going to attack them back to get them away from me, we're not just going to randomly go up to people and attack them. It's self-defense in the aspect that that's the only way to keep people away from them. If they're attacked, they're going to attack back. That's the self-defense part and that's ... when the violence is incorporated ... and also, separation, if we separate from the white people, if they try to use force to take our communities then we're going to use force and violence against them."

S3: "That's retaliation."

S1: "Everything you're talking about is just only going to do more violence, we attack them, they're, we're going to attack them back, and it's just going to turn into some kind of a shoving match until we separate, and then there's still going to be all this conflict between these two people."

S2: "When we attack back, we're going to be strong enough so that the white people won't come back."

S1: "It's always going to be strong enough, but they're always going to come back."

S4: “Nonviolent protestors have been protesting for hundreds of years, it didn't work, the Black Panthers came along in the 60 s and you see how much got done, look at us now. Exactly!" [laughter]

Tim: "You're, you're equating equality with what the Black Panthers did."

S4: "I'm not saying they [Black Panthers] were completely responsible, I'm saying it's part of their movement and ... the government and different law enforcement agencies realizing that, 'Hey, these people are going to fight back,' you know, it's going to make them think twice before they send dogs after them and shoot them with fire hoses."

Tim: "[S5]."

- volume 2 , no. 1 
S5: "I think what a lot of people don't understand is that, what they did was give a lot of black people a will to fight ... they gave them something to stand up for ... that Black Power thing ... that raised their motivation, gave them a reason to fight. Before then, they wanted to fight back but they didn't get anything done and when the Black Panthers came along they gave them something to do, a way to get involved."

In this example, it should be noted that the most vocal proponents of the separatists' perspective were middle-class white students who were accurately conveying a perspective that could be reasonably expected to be different in both chronological and cultural perspective from their own personal views. In addition, at the end of the dialogue, two students discussed how the philosophy promoted by the separatists would make people "think twice before they send dogs after them" and how the separatist movement provided African-Americans with "a will to fight" and "something to stand up for." In both of these cases, the students were explaining why the actions taken by the separatists were understandable and perhaps even justified at that time in history. We hypothesize that discussions such as these may have been encouraged by more realistic encounters with events and actors available in the DP resources, and by providing students with opportunities to entertain a perspective (e.g., the views represented by the separatists) that they may not have considered prior to the DP unit.

A similar example of historical empathy can be found in the following excerpt of a class discussion. In this closing discussion following the presentations of two separatist groups, the teacher prompted the class to identify potential problems with the separatist strategy. The teacher's goal was to have students take a dispassionate historical view of the strategy and its prospects for success in reaching its goals in 1968. However, students representing the separatists continued to defend the separatist position:

Tim: "What kinds of problems do you see with this [the separatist view] ...?"

S1: "They don't want to be together. All of these [groups] suppressed blacks, and in the end they realized that there were a few that liked black people, but the rest of them [white people] are just ignorant and there's no point in the black people being slowed down and they should just get away from them...."

S2: "At the time, [separation] seemed like a good idea, because segregation wasn't working and they could see by the way they were treated when they tried nonviolent protest, how are they going to walk down the same halls and share the same bathrooms and eat in the same restaurants as these people, at the time it looked impossible so you can see why they moved towards separation...."

Tim: "That's a great point. We've got the benefit of looking back 30 years..." 
Here, students once again were justifying the strategies proposed by the separatists by placing themselves in the separatists' situation at that point in time. By sustaining the argument that separation was justifiable based on the way African-Americans were treated by whites, students were indicating that they cared about the ill-treatment of African-Americans during this time period.In addition, by stating, "At the time, separation seemed like a good idea," one could argue that the student was actively putting herself in the position of the separatists in the late 1960s. The student used the argument that nonviolent protest seemed to be ineffective in eliminating segregation as justification for a move toward separation of the races. Although this idea may seem radical to many today, the student makes a strong argument from the perspective of those engaged in the struggle at that moment in history - that separation was a valid strategy in order for African-Americans to gain equal rights in the 1960 s.

These discussions also suggest a link between engagement and the development of historical empathy. Through use of multimedia resources such as those available in the DP environment, students encountered more realistic representations of the viewpoints represented by historical figures during that time period (Spoehr \& Spoehr, 1994). These encounters may have engaged students to the point where they genuinely cared about (and seriously entertained) the issues and dilemmas faced by individuals in this time period. This combination of engagement and empathy may have facilitated students' abilities to debate those issues in a sustained, authentic conversation.

Comments made by students during post-unit interviews provided additional evidence that the unit may have assisted in providing students with empathetic views for diverse perspectives on the civil rights movement. These data support the assertion that the DP problem-based unit may have had a positive impact on students' abilities to engage in historical empathy when interpreting past events. For example, when asked if the DP unit activities helped her gain a better perspective of the time period, one student responded:

It will in this case. You really get a taste for the, just the whole lifestyle and the whole, not just the actual fact, once again going back to fact, not just the fact of what happened in that time period, but the overriding, like, uh, historically how the society was set up and how, you see in these, in these things, you know, what life was like in that period, which has a lot to do with how you interpret the facts.

The teachers also believed that the DP unit activities assisted students with acquiring more empathetic views of the events associated with the civil rights movement, particularly with regard to perspective-taking. As Craig stated, "They were hitting on all the key points in research they were doing. They weren't seeing it as the textbook gives it. They were seeing it as from the eyes of those who lived it. They were making an 
argument for those that they were researching, what they would have done." Craig also discussed how the activities assisted students with understanding some of the controversial issues associated with the civil rights movement, and caring about those issues: "They actually got into the heart of issues and groups of people and what they were really feeling and why they disagreed with this group who was fighting for the same cause. That's something I had to think was totally new to them."

\section{Epistemic Assumptions About the History}

Analysis of interview data suggested that students participating in the DP unit tended to present distinct viewpoints regarding the nature of history and the usefulness of historical inquiry as it applied to their interpretations of civil rights events. These data indicated that some students maintained the belief in a single "correct" interpretation of various events. For example, one student described how examining the variety of data available in the database assisted with understanding what actually occurred:

Well, even though they all have their own opinions, what actually went on that we, I think that we all understood that the event, or the chain of events that happened, even though there was people that saw it differently, but what actually happened, you know, we understood that. Like the boycotts and stuff, you know, that's stuff that actually happened.

While discussing the benefits of the multimedia available in the databases, another student stated, "You just understand it better because you can see, uh, why there is, for example, controversy. You can understand where these people are coming from.... So, I think [the multimedia] just helps, helps you understand where these people are coming from and what exactly was going on."

Even though both of these students discussed the benefits that the multimedia database provided in giving them access to more authentic information about the movement, history educators may not view this outcome as wholly desirable. Historians see history as an interpretation from evidence trails rather than a faithful reconstruction of an event (VanSledright, 2002). In this case, the students may have believed they understood "what exactly was going on." This attitude may represent a potential danger of providing access to more realistic primary and secondary sources (such as photographs and video footage of historical events). Students may view these sources as immune to the biases associated with textual information, and thus more readily accept these sources as "what actually happened."

In contrast to those students who seemed to view the past in absolutist terms, data demonstrated to other students that interpreting historical events was many times a series of "opinions" without a real way of knowing which viewpoint or interpretation was most plausible. As one student stated,"If you try to figure it [a historical event] out, you're 
probably going to be wrong." When asked how she decided what the correct interpretation of an historical event was when she was given information that supported competing accounts of that event, another student replied:

I really don't know.... You can't really say if you have those primary sources for sure, this is exactly what happened and my opinion is right and it's the only opinion. Because everyone had an opinion back then ... I do believe that a large portion of it is opinion and um, we see that, I guess.

During a post-unit interview, another student had a similar perception of the difficulties with truly understanding the causes of historical events:

S: "A lot of other different speculations would happen, you get different views from other people."

Researcher: "Um, hum. So how do we ever really know what happened?"

S: "We really don't."

Researcher: "You don't?"

S: "They say the Great Depression was caused by the fall of the stock market, but who knows whether it was the stock market or not. That's what makes history so funny, you don't know nothing till you break it down. So in the end, it's gonna be somebody's opinion."

These comments demonstrate some of the challenges students face as they struggle to conduct disciplined historical inquiry. In the preceding examples, students had moved away from the belief in a "correct" interpretation of history-however, they seemed to conclude that because individual accounts of historical events were nothing more than opinion, that they had no real way of making defensible conclusions about the past. These data suggest that students were moving toward a more multiplist view of history, but they had yet to demonstrate more advanced evaluative views in which they would be able to assess the validity of the competing points of view in order to develop their own evidence-based interpretation of the event (Kuhn, 1999, 2005).

These findings are consistent with other research detailing the difficulties students have drawing conclusions from multiple sources (Ashby \& Lee, 1998; Barton \& Levstik, 2004; VanSledright, 2002). As Barton and Levstik (2004, p. 196) stated, "[Learners] conclude that historical sources are always biased and incomplete, so there is no way of deciding what happened-one idea is as good as another." However, these results do demonstrate that students acknowledged the existence of multiple views of a historical 
event. Assisting students in moving from a multiplist to an evaluative epistemological stance remains an unresolved challenge in our research with DP problem-based units and for history and civics educators in general.

\section{Addressing the Challenges of Problem-based Inquiry in History}

The results of this research have assisted us in refining our conceptions regarding the design of activities and support structures to address the challenges of problem-based inquiry in high school history, and suggested upper limits for what we may reasonably expect to accomplish with scaffolding support. A few existing field studies (e.g., VanSledright, 2002) have examined how we may support learners in small, well-defined reasoning tasks. Our line of research expands those inquiries to address the more complex challenge of supporting students as they attempt to make reasoned decisions about broader ill-structured social problems.

Although these results provide some support to previous studies espousing the benefits of scaffolded multimedia learning environments to support problem-based inquiry (e.g., Choi \& Hannafin, 1995; Hmelo-Silver, Duncan, \& Chinn, 2007; Jacobsen, Maouiri, Mishra, \& Kolar, 1996; Land \& Zembal-Saul, 2003; Masterman \& Rogers, 2002; Reiser, 2004), we do not wish to promote either technology or problem-based inquiry as a panacea for the challenges teachers and students face when engaging in disciplined inquiry in history. In fact, data from this study demonstrate that two major challenges remain for both teachers and students during problem-based inquiry activities: (1) improving the quality of students' solutions to complex historical problems, and (2) guiding students toward more evaluative epistemological understandings of history.

Improving the quality of students' solutions to complex historical problems. After completion of the unit described in this study, the teachers remained disappointed with the quality and depth of student presentations addressing the central problem of the unit. Both teachers implied that they may have been able to use the scaffolds designed to support development of the culminating presentations (i.e., the storyboard template and presentation tool) more effectively with their students, and that they underestimated the complexity of the task and the amount of support students needed to engage in complex reasoning about the unit problem. As Tim stated:

I'm not sure they really saw the distinct difference that they needed to see between the very different ways of achieving civil rights ... when they were doing their presentations, they didn't do a very good job overall of taking media and placing it in the context of their arguments, what their goals were, what their arguments for the strategy or what their recommendation was against it. Some of the groups did not do that very well. They didn't support what they were doing with evidence. 
Craig agreed, stating, "They understood the little pieces, but putting those pieces into a historical context and understanding the context in an intelligible way, that was the hurdle I don't think I helped them over, not as a group."

In addition to the "hard" scaffolds (i.e., supports integrated within the DP multimedia environment such as the embedded hyperlinks, student guides, and presentation tool) available to students, both teachers suggested that additional situation-specific, or "soft" scaffolding (Saye \& Brush, 2002) by the teacher is necessary for students to more deeply engage in the problem and address the multiple potential solutions to the problem. This type of scaffolding may be particularly critical as students are synthesizing evidence in order to develop an argument in support of a strategy (Reiser, 2004).

Pea (2004) supports the need for both "hard" and "soft" scaffolds within a learning environment when he states, "It seems possible to imagine 'mixed initiative' designs of scaffolding processes in which people and machines join together in helping someone learn something in the sense that certain scaffolding activities can be the responsibility of the teacher ... and other scaffolding activities provided by the software" (p.444). Our next challenge is to determine what supports are best provided by software and what supports are best provided by the teacher to optimally facilitate historical problem solving among students. For example, opportunities to assist students with integrating discrete pieces of historical evidence into a broader historical context may be integrated into future iterations of the DP unit via additional small-group discussion sessions with the teacher as students are generating their problem solutions (Saye \& Brush, 2004)—a support strategy that would be difficult to provide as a "hard" scaffold.

The perceived superficiality of students' presentations may also be related to the design of the overall DP unit, and students' abilities to acquire deep, broad views of the civil rights knowledge base through the unit activities. Although one of the espoused benefits of problem-based inquiry is a deeper and more flexible knowledge base relevant to the problem (Hmelo-Silver, 2004), we hypothesize that in this particular unit, the problem was too expansive for students to achieve mastery in the time allotted to the unit. Both of the teachers expressed surprise at the length of time many students needed to complete unit activities, and concluded that they felt they may have "rushed" the students in order to complete the unit within the number of classes they had allocated. These data suggest that multimedia resources such as those available in DP might be used more effectively if initial problems explored by students are smaller, more bounded, and thus more manageable within the limited time a teacher may have available to any particular topic (Jonassen, 1997; Saye \& Brush, 2002).

In addition, we hypothesize that additional support structures embedded within the DP environment may facilitate students' abilities to more effectively interpret historical events and develop more complex solutions to unit problems. For example, by encouraging students to use the contextual links embedded within the interactive 
essays to navigate to relevant primary sources, teachers can help provide students a context with which to relate primary information to the overall event being studied. Pea (2004) describes this form of scaffolding as "focusing," in which the scaffold serves to focus learner attention on relevant resources needed to solve a complex problem. Hmelo-Silver, Duncan, and Chinn (2007) discuss the need for scaffolds that embed expert guidance for students. For the DP unit, this approach may involve more explicit guidance for analyzing an historical event and/or document, or providing students with additional models of culminating presentations. Additional support structures such as these may help guide students to information that will assist them in constructing deeper understandings of the unit problem, and thus developing more thoughtful solutions.

Guiding students toward more evaluative epistemological understandings of history. As stated previously, data from this study indicated that students tended to maintain either absolutist (i.e.,"There is one correct version of an historical event") or multiplist (i.e., "Everyone's interpretation of an historical event is just their opinion") epistemological assumptions about history. We found little evidence that students had progressed toward evaluative epistemological understandings, where "judgments ... can be evaluated and compared according to criteria of argument and evidence" (Kuhn, 2005, p. 31). To reach this point, students need to recognize that different interpretations are generally the result of different frames of reference, and then have the dispositions and skills to take those varied interpretations, weigh the merits of each, and construct their own judgment about what they suggest about an event.

As with the previous challenge, scaffolds embedded within the DP environment may be able to influence students' epistemic beliefs about history. The interactive essays, for example, may assist students in more readily examining multiple representations and interpretations of historical events. During a post-unit interview with one of the researchers, one student discussed the usefulness of the variety of viewpoints available by following the links embedded within the interactive essays:

S: “...just to see, different people's viewpoints on one subject, I mean, you have, probably twelve different viewpoints, you know, these links, on one subject, so you could get ... a segregationists point of view, you know, from different people, which is interesting, which is always good when you're doing a project like this.... It's really helpful to have different viewpoints to look at and to choose from so you can get kind of an overview of the opposing sides and what they thought, so I like that."

R: "Is that different in the way that you normally encounter historical accounts and studying history? Do you normally get different points of view like that?"

S: "Not, well, in the text, usually not, I mean, let's face it, I guess maybe U.S. or history texts can be a little bit biased and can be not so truthful to different points 
of view. So, I'd have to say now that you don't really get as much of that with a text or with a single source than you would with something like this software where you have more than one point of view."

This student believed that by using the contextual links embedded within the interactive essays to navigate to relevant primary sources, he had a context with which to relate primary information to the overall event being studied and was able to more easily examine a variety of viewpoints related to the event he was studying than he would if he were using a textbook.

Another use of hyperlinks embedded within interactive essays that we are exploring is the use of the links to intentionally juxtapose competing accounts of a historical event, thus providing additional "channeling and focusing" (Pea, 2004) support in order to assist students in more readily acknowledging and accounting for multiple representations and interpretations of historical events. Figure 6 demonstrates how these hyperlinks could guide students to various viewpoints (in this case, competing perspectives regarding strategies to pursue in Birmingham, Alabama, in 1963) in order to provide them with an opportunity to explore the evaluative and tentative nature of historical events.

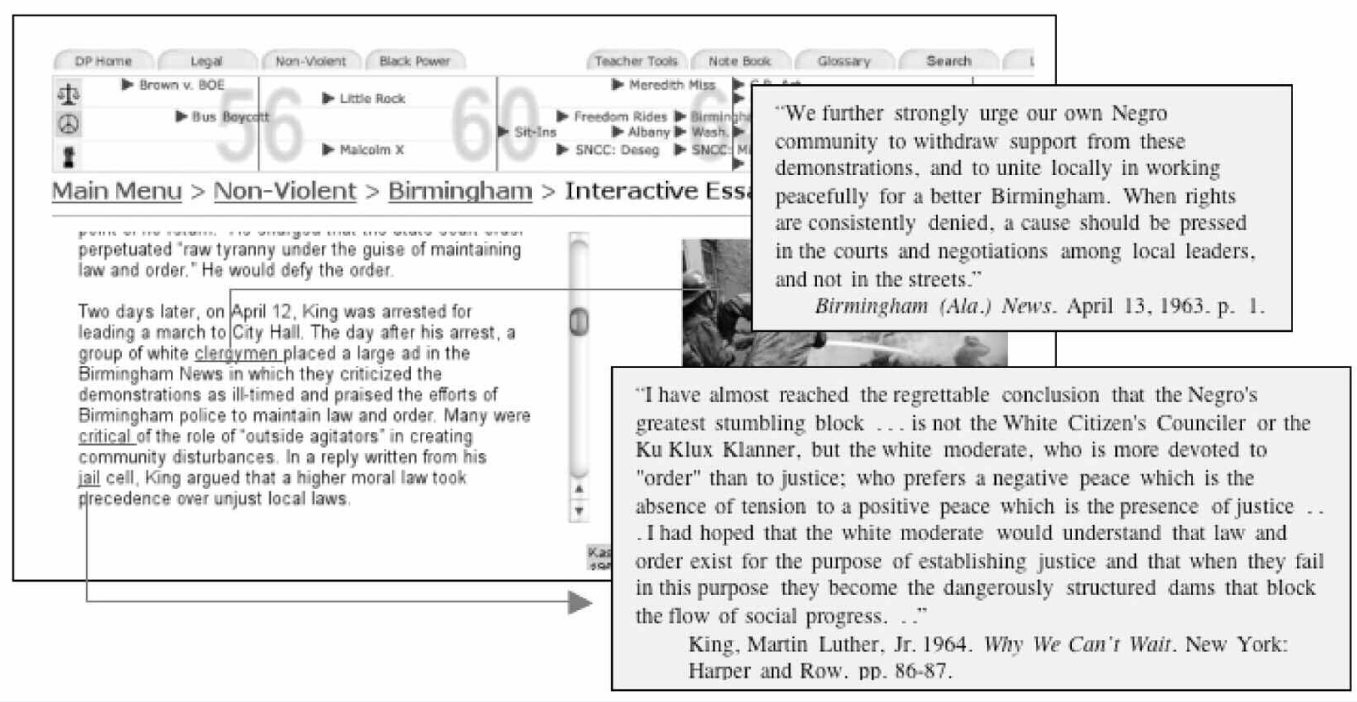

Figure 6. Embedded links to competing accounts of an event.

Enhancing activities already integrated into the DP problem-based unit may also offer an enabling context for promoting more evaluative epistemological understanding. The culminating presentations, for example, offered the classroom teachers the opportunity to scaffold student thinking by providing them with this "socialization aspect" of problem-solving (Reiser, 2004), allowing students to grapple with competing 
interpretations of historical events during discussions generated from the presentations. During these presentations, teachers could promote dialogue among students in order to facilitate deeper understanding of controversial issues, multiple interpretations of historical events, and to force students to weigh evidence in order to determine the most plausible interpretations of those issues. Kolodner and colleagues (2003) successfully incorporated this "present and share" strategy in their Learning By Design model of problem-based inquiry for science.

The format of the culminating presentations may also provide teachers with the opportunity to model more expert historical thinking and guide the students in examining different interpretations of the event based on the information provided in the DP database. The use of modeling has been found to be a highly effective method for scaffolding student thinking (Pea, 2004; Reiser, 2004). In addition, the open dialogue and discussions generated during the culminating presentations may allow students to benefit from their peers who interpreted historical evidence differently or at a deeper evaluative level. Interactions such as these may provide students with opportunities to weigh competing interpretations of historical events and draw conclusions based on the evidence available, as opposed to opinion and conjecture, thus providing the mechanism for more evaluative epistemological understandings of history (Spoehr \& Spoehr, 1994).

\section{Conclusion: Using the Past to Inform the Present}

In conclusion, we believe that students' interactions with the DP problem-based unit may have provided them with a new perspective on the usefulness of understanding historical events as a means for making decisions as members of a democratic society. We hypothesize that the realism and increased empathy for historical actors provided through participation in the DP unit may have allowed students to see more relevance for how the past relates to their own lives. Although historians take issue with the notion that "history repeats itself," citizens and policy makers do commonly "draw lessons" from the past (Khong, 1992; Levstik \& Barton, 2001). One of our continued challenges with students is to help them recognize the uniqueness of historical events while they also use historical understandings to think about contemporary issues. The potential of scaffolded multimedia problem-based activities to engage students with the complexity of historical issues may provide them with richer understandings of the past that they can use to inform their decisions about the present. 


\section{Acknowledgment}

Portions of this work were supported by grants from the National Endowment for the Humanities (Grant ED-22175-02), Apple Computer, Auburn University College of Education, Indiana University, and Auburn City Schools.

\section{References}

Ashby, R. \& Lee, P. (1998, April). Information, opinion, and beyond. Paper presented at the annual meeting of the American Educational Research Association, San Diego, CA.

Ashby, R. \& Lee, P. (1987). Children's concepts of empathy and understanding in history. In C. Portal (Ed.), The history curriculum for teachers (pp. 62-88). London: Falmer Press.

Barrows, H. \& Kelson, A.C. (1995). Problem-based learning in secondary education and the Problem-based Learning Institute (Monograph 1). Springfield, IL: Problem-based Learning Institute.

Barton, K.C. \& Levstik, L.S. (2004). Teaching history for the common good. Mahwah, NJ: Lawrence Erlbaum Associates.

Brown, A. L. (1992). Design experiments: Theoretical and methodological challenges in creating complex interventions in classroom settings. Journal of Learning Sciences 2(2), 141-178.

Brown, J. S., Collins, A., \& Duguid, P. (1989). Situated cognition and the culture of learning. Educational Researcher, 18 (1), 32-41.

Brush, T. \& Saye, J. W. (2004). Supporting learners in technology-enhanced student-centered learning environments. International Journal of Learning Technology, 1(2), 191-202.

Brush, T. \& Saye, J.W. (2001). The use of embedded scaffolds with hypermedia-supported student-centered learning. Journal of Educational Multimedia and Hypermedia, 10(4), 333-356.

Brush, T. \& Saye, J.W. (2000). Implementation and evaluation of a student-centered learning unit: A case study. Educational Technology Research and Development, 48(3), 79-100.

Choi, J. \& Hannafin, M. (1995). Situated cognition and learning environments: Roles, structures, and implications for design. Educational Technology Research and Development, 43(2), 53-69.

Cobb, P., Confrey, J., diSessa, A., Lehrer, R., \& Schauble, L. (2003). Design experiments in educational research. Educational Researcher, 32(1), 9-13.

- volume 2, no. 1 
Cognition and Technology Group at Vanderbilt. (1993). Anchored instruction and situated cognition revisited. Educational Technology, 33(3), 52-70.

Cognition and Technology Group at Vanderbilt (CTGV). (1992). The Jasper experiment: An exploration of issues in learning and instructional design. Educational Technology Research and Development, 40(1), 65-80.

Collins, A., Joseph, D., \& Bielaczyc, K. (2004). Design research: Theoretical and methodological issues. Journal of the Learning Sciences, 13(1), 15-42.

Denzin, N. (1989). The research act: $A$ theoretical introduction to sociological methods, 3rd ed. Englewood Cliffs, NJ: Prentice Hall.

Dundis, S. P. \& Fehn, B. R. (1999). Historical thinking skills and conceptualized archives: Exploring the American Journey CD-ROMs. The Social Studies, 90(6), 273-277.

Dwyer, D. (1994). Apple classrooms of tomorrow: What we've learned. Educational Leadership, 51(7), 4-10.

Enyedy, N. (2003). Knowledge construction and collective practice: At the intersection of learning, talk, and social configurations in a computer-mediated mathematics classroom. The Journal of the Learning Sciences, 12(3), 361-407.

Geier, R., Blumenfeld, P., Marx, R., Krajcik, J., Fishman, B., \& Soloway, E. (in press). Standardized test outcomes for students engaged in inquiry-based science curriculum in the context of urban reform. Journal of Research in Science Teaching.

Goetz, J., \& LeCompte, M. (1984). Ethnography and qualitative design in educational research. San Diego, CA: Academic Press.

Gordon, R. (1998). Balancing real-world problems with real world results. Phi Delta Kappan, 27(1), 390-393.

Hannafin, M., Hill, J., \& Land, S. (1997). Student-centered learning and interactive multimedia: Status, issues, and implication. Contemporary Education, 68(2), 94-99.

Hannafin, M., Land, S., \& Oliver, K. (1999). Open learning environments: Foundations, methods, and models. In C. Reigeluth (Ed.), Instructional design theories and models, Vol. II, Mahwah, NJ: Lawrence Erlbaum Associates.

Hickey, D. T., Moore, A. L., \& Pellegrino, J.W. (2001). The motivational and academic consequences of elementary mathematics environments: Do constructivist innovations and reforms make a difference? American Educational Research Journal, 38(3), 611-652.

Hmelo-Silver, C. (2006). Design principles for scaffolding technology-based inquiry. In A.M.O'Donnell, C.E. Hmelo-Silver, \& G. Erkens (Eds.). Collaborative reasoning, learning and technology (pp. 147-170). Mahwah, NJ: Lawrence Erlbaum Associates.

Hmelo-Silver, C. (2004). Problem-based learning: What and how do students learn? Educational Psychology Review, 16(3), 235-266. 
Hmelo-Silver, C., Duncan, R., \& Chinn, C. (2007). Scaffolding and achievement in problembased and inquiry learning: A response to Kirschner, Sweller, and Clark. Educational Psychologist, 42(2), 99-107.

Holt, T. (1990). Thinking historically: Narrative, imagination, and understanding. New York: College Entrance Examination Board.

Hynd, C., Hubbard, B., Holschuh, J., Reinking, D., Jacobson, M. (2000, April). Reading like a historian: Critical reading of multiple texts in a hypertext environment. Paper presented at the American Educational Research Association, New Orleans, LA.

Jacobsen, M. J., Maouiri, C., Mishra, P., \& Kolar, C. (1996). Learning with hypertext learning environments: Theory, design and research. Journal of Educational Multimedia and Hypermedia, 5(3/4), 239-281.

Jacobson, M. \& Spiro, R. (1994). A framework for the contextual analysis of technologybased learning environments. Journal of Computing in Higher Education, 5(2), 3-32.

Jonassen, D. (1999). Designing constructivist learning environments. In C. M. Reigeluth (Ed.), Instructional Design Theories and Models, Vol. 2, pp. 89-121. Mahwah, NJ: Lawrence Erlbaum Associates.

Jonassen, D. (1997). Instructional design models for well-structured and ill-structured problem-solving learning outcomes. Educational Technology Research and Development, 45(1), 65-94.

Khong, Y. F. (1992). Analogies at War. Princeton, NJ: Princeton University Press.

Kinzie, M. \& Sullivan, H. (1989). Continuing motivation, learner control, and CAI. Educational Technology Research and Development, 37(2), 5-14.

Kolodner, J., Camp, P., Crismond, D., Fasse, B., Gray, J., Holbrook, J., Puntambekar, S., \& Ryan, M. (2003). Problem-based learning meets case-based reasoning in the middleschool science classroom: Putting Learning by Design into practice. The Journal of the Learning Sciences, 12(4), 495-547.

Kuhn, D. (2005). Education for thinking. Cambridge, MA: Harvard University Press.

Kuhn, D. (1999). A developmental model of critical thinking. Educational Researcher, 28(2), $16-26,46$.

Land, S. \& Zembal-Saul, C. (2003). Scaffolding reflection and articulation of scientific explanations in a data-rich, project-based learning environment: An investigation of Progress Portfolio. Educational Technology Research and Development, 51(4), 65-84.

Levstik, L. S. \& Barton, K. C. (2001). Committing acts of history: Mediated action, humanistic education, and participatory democracy. In W. Stanley (Ed.), Critical Issues in Social Studies Research for the 21st Century (pp. 119-147). Greenwich, CN: Information Age Publishing.

- volume 2 , no. 1 
Linn, M., Shear, L., Bell, P., \& Slotta, J.D. (1999). Organizing principles for science education partnerships: Case studies of students' learning about "rats in space" and "deformed frogs." Educational Technology Research and Development, 47(2), 61-84.

Loh, B., Reiser, B., Radinsky, J., Edelson, D., Gomez, L., \& Marshall, S. (2001). Developing reflective inquiry practices: A case study of software, the teacher, and students. In K. Crowley, C. Schunn, \& T. Okada (Eds.), Designing for Science: Implications from Everyday, Classroom, and Professional Settings. Mahwah, NJ: Lawrence Erlbaum Associates.

Masterman, E. \& Rogers, Y. (2002). A framework for designing interactive multimedia to scaffold young children's understanding of historical chronology. Instructional Science, 30, 221-241.

Mergendoller, J. R., Maxwell, N. L., \& Bellisimo, Y. (2006). The effectiveness of problembased instruction: A comparative study of instructional methods and student characteristics. The Interdisciplinary Journal of Problem-based Learning, 1(2), 49-69.

Miles, M. \& Huberman, A. (1994). Qualitative Data Analysis: An Expanded Sourcebook, 2nd ed. Thousand Oaks, CA: Sage.

Newmann, F. M. (1991). Higher order thinking in the teaching of social studies: Connections between theory and practice. In J. Voss, D. Perkins, \& J. Segal (Eds.), Informal reasoning and education (pp. 381-400). Hillsdale, NJ: Lawrence Erlbaum Associates.

Newmann, F. M. (1991b). Classroom thoughtfulness and students' higher order thinking: Common indicators and diverse social studies courses. Theory and Research in Social Education, 19(4), 410-433.

Newmann, F. \& Associates. (1996). Authentic achievement: Restructuring schools for intellectual quality. San Francisco, CA. Jossey-Bass.

Newmann, F. M., Wehlage, G. G., \& Lamborn, S. D. (1992). The significance and sources of student engagement. In F. Newmann (Ed.), Student engagement and achievement in American secondary schools (pp. 11-39). New York: Teachers College Press.

Onosko, J. (1991). Barriers to the promotion of higher order thinking in social studies. Theory and Research in Social Education, 19(4), 341-366.

Parker, W. C., Mueller, M., \& Wendling, L. (1989). Critical reasoning on civic issues. Theory and Research in Social Education, 17(1), 7-32.

Pea, R. (2004). The social and technological dimensions of scaffolding and related theoretical concepts for learning, education, and human activity. The Journal of the Learning Sciences, 13(3), 423-451.

Pedersen, S. \& Liu, M. (2003). Teachers' beliefs about issues in the implementation of a student-centered learning environment. Educational Technology Research and Development, 51(2), 57-76. 
Perfetti, C. A., Britt, M. A., Dyke, J.V., \& Gabrys, G. (1999, April). The sourcer's apprentice: A program of research and development in history instruction. Paper presented at the American Educational Research Association, Montreal, Canada.

Perkins, D. N., Allen, R., \& Hafner, J. (1983). Difficulties in everyday reasoning. In W. Maxwell (Ed.), Thinking:The expanding frontier (pp. 177-189). Philadelphia: Franklin Institute.

Ravitz, J. \& Mergendoller, J. (2005, April). Evaluating implementation and impacts of problem-based economics in U.S. high schools. Paper presented at the Annual Meeting of the American Educational Research Association, Montreal, Canada.

Reiser, B. (2004). Scaffolding complex learning:The mechanisms of structuring and problematizing student work. The Journal of the Learning Sciences, 13(3), 273-304.

Rossi, J. A. (1995). In-depth study in an issues-centered social studies classroom. Theory and Research in Social Education, 23(2), 87-120.

Savery, J. (2006). Overview of problem-based learning: Definitions and distinctions. The Interdisciplinary Journal of Problem-based Learning, 1(1), 9-20.

Saye, J. W. \& Brush, T. (In press). Using technology-enhanced learning environments to support problem-based historical inquiry in secondary school classrooms. Theory and Research in Social Education.

Saye, J.W.\& Brush, T. (2004). Promoting civic competence through problem-based history learning experiments. In G. E. Hamot, J. J. Patrick, \& R. S. Leming (Eds.), Civic Learning in Teacher Education, Vol. 3, pp. 123-145). Bloomington, IN: The Social Studies Development Center.

Saye, J.W. \& Brush, T. (2002). Scaffolding critical reasoning about history and social issues in multimedia-supported learning environments. Educational Technology Research and Development, 50(3), 77-96.

Saye, J.W. \& Brush, T. (1999). Student engagement with social issues in a multimedia-supported learning environment. Theory and Research in Social Education 27(4), 472-504.

Shaver, J. P. (1996). The prospects of issue-centered education. In D. W. Saxe (Ed.), Handbook on teaching social issues (pp.380-386). Washington, DC: National Council for the Social Studies.

Shaver, J. P., Davis, O. L., \& Helburn, S. W. (1979). The status of social studies education: Impressions from three NSF studies. Social Education, 4(3), 150-153.

Simons, K. \& Klein, J. (2007). The impact of scaffolding and student achievement levels in a problem-based learning environment. Instructional Science, 35(1), 41-72.

Spiro, R., Collins, B., \& Thota, J. (2003). Cognitive flexibility theory: Hypermedia for complex learning, adaptive knowledge application, and experience acceleration. Educational Technology, 43(5), 5-10.

- volume 2 , no. 1 
Spiro, R. J. \& Jehng, J. C. (1990). Cognitive flexibility and hypertext: Theory and technology for the nonlinear and multidimensional traversal of complex subject matter. In D. Nix \& R. Spiro (Eds.). Cognition, ducation, and ultimedia (pp. 163-205). Hillsdale, NJ: Lawrence Erlbaum Associates.

Spoehr, K. \& Spoehr, L. (1994). Learning to think historically. Educational Psychologist, 29(2), 71-77.

Stake, R. (1995). The Art of ase Study Research. Thousand Oaks, CA: Sage.

VanSickle, R. L., \& Hoge, J. D. (1991). Higher cognitive thinking skills in social studies: Concepts and critiques. Theory and Research in Social Education, 19(2), 152-172.

VanSledright, B. (2002). Confronting history's interpretive paradox while teaching fifth graders to investigate the past. American Educational Research Journal, 39(4), 1089-1115.

Wang, F. \& Hannafin, M. (2005). Design-based research and technology-enhanced learning environments. Educational Technology Research and Development, 53(4), 5-23.

Wineburg, S. (1999). Historical thinking and other unnatural acts. Phi Delta Kappan, 80(7), 488-499.

Wineburg, S. (1991). Historical problem solving: A study of cognitive processes used in the evaluation of documentary and pictorial evidence. Journal of Educational Psychology, 83(1), 73-87.

Yeager, E. A. \& Foster, S. J. (2001). The role of empathy in the development of historical understanding. In O. L. Davis, Jr., E. A. Yeager, \& S. J. Foster, (Eds.), Development of Historical Empathy: Perspective Taking in the Social Studies. Lanham, MD:Rowman and Littlefield Publishers, Inc.

Yin, R. (2003). Case study research:Design and methods, 3rd Ed. Thousand Oaks, CA: Sage. Zukas, A. (2000). Active learning, world history, and the Internet: Creating knowledge in the classroom. International Journal of Social Education, 15(1), 62-79.

Dr. Thomas Brush is an Associate Professor of Instructional Systems Technology at the School of Education, Indiana University, Bloomington, and co-director of the Persistent Issues in History project. Dr. Brush can be reached via email at tbrush@indiana.edu.

Dr. John Saye is a Professor of Secondary Social Studies Education at the College of Education, Auburn University, Auburn, Alabama, and co-director of the Persistent Issues in History project. Dr. Saye can be reached via email at sayejoh@auburn.edu.

Correspondence concerning this article should be addressed to Thomas Brush, Department of Instructional Systems Technology, W. W. Wright Education Building, Room 2276, 201 North Rose Avenue, Bloomington, IN 47405-1006, USA. 